\title{
Mechanical Properties of Paricá Wood Using Structural Members and Clear Specimens
}

\author{
Raquel Schmitt Cavalheiro ${ }^{1}$, Diego Henrique de Almeida ${ }^{2, *}$, Tiago Hendrigo de Almeida ${ }^{1}$, \\ Victor Almeida de Araújo ${ }^{3}$, André Luís Christoforo ${ }^{4}$, Francisco Antonio Rocco Lahr ${ }^{5}$
}

\begin{abstract}
${ }^{1}$ Department of Materials Engineering (SMM), Engineering School of São Carlos (EESC), São Paulo University (USP), São Carlos, Brazil ${ }^{2}$ Pitágoras Faculty, Department of Engineering, Poços de Caldas Campus, Poços de Caldas, Brazil

${ }^{3}$ Research Group LIGNO of UNESP-Itapeva, Department of Forest Sciences, School of Agriculture Luiz de Queiroz of University of São Paulo (ESALQ/USP), Piracicaba, Brazil

${ }^{4}$ Centre for Innovation and Technology in Composites (CITeC), Department of Civil Engineering (DECiv), Federal University of São Carlos (UFSCar), São Carlos, Brazil

${ }^{5}$ Department of Structures Engineering (SET), Engineering School of São Carlos (EESC), São Paulo University (USP), São Carlos, Brazil
\end{abstract}

\begin{abstract}
The aim of this research is determining mechanical properties of Paricá wood specie (Schizolobium amazonicum Herb) using structural and clear specimens, according to Brazilian standard ABNT NBR 7190 requirements. Paricá wood specie in structural members, with moisture content of around $12 \%$, were determined dynamic elasticity modulus (transverse vibration tests), static bending modulus (three point bending) and modulus of rupture in static bending test. In clear specimens, according to Brazilian standard were determined compression, shear, embedment and tension parallel to the grain, and the elasticity modulus in compression and tension parallel to the grain. It is concluded that the Paricá wood specie present good strengths properties, although of low density, presenting potential for use in timber structures.
\end{abstract}

Keywords Physical properties, Mechanical properties, Structural members, Specific gravity, Paricá wood specie

\section{Introduction}

Wood is used as a structural material since early times, when emerged man's need to protect themselves by building shelters for their safety and to overcome all kinds of weathering.

In Brazil, because of operating major national biomes (for example, Amazon and Atlantic Forests) without proper planning, the use of native wood species has been restricted, intending not to extinguish such species. In addition, new building technologies require availability of easy-acquisition lumber, mainly when dealing industrialized timber structures.

Construction of timber structures needs special care, including: chemical pre-treatment, knowledge of physical and mechanical properties and a design according to standard documents [1-4].

The characterization of wood properties is an important and determining factor for their use in a rational way. Different physical and mechanical properties are found among different tree species (coniferous and dicotyledonous), among trees of the same species and in

* Corresponding author:

diegoestruturas@gmail.com (Diego Henrique de Almeida)

Published online at http://journal.sapub.org/ijme

Copyright $(C 2016$ Scientific \& Academic Publishing. All Rights Reserved different points of the same tree $[3,5,6]$.

The Brazilian standard ABNT NBR 7190 [7] defines three different ways to perform the characterization of wood properties: full characterization, minimum characterization and simplified characterization. For the full characterization of a species is necessary to perform standard laboratory tests in accordance with Annex B of ABNT NBR 7190:1997 [7], "Determination of the properties of wood for structural designs".

In addition, it is possible to estimate the strength and stiffness properties of the wood by visual grading of structural timber members. This classification is based on the identification of defects on structural elements of wood, such as: nodes, inclined grain, cracks and crevices, processing defects, among others [8-11].

The method of transverse vibration is a non-destructive method based on the natural frequency of the wood bi-supported (with a load cell installed in one of the supports), ordered with an impact in the middle of the span between supports [12]. The load cell captures the vibration of the timber member and transfers the signal to a conditioning circuit, which amplifies and filters the vibration, after this signal is digitized and sent to a computer that determines the frequency of the oscillating signal (Fig. 1). Knowing the dimensional characteristics of the timber member and its mass, the software itself provides the value of the dynamic modulus of elasticity. 


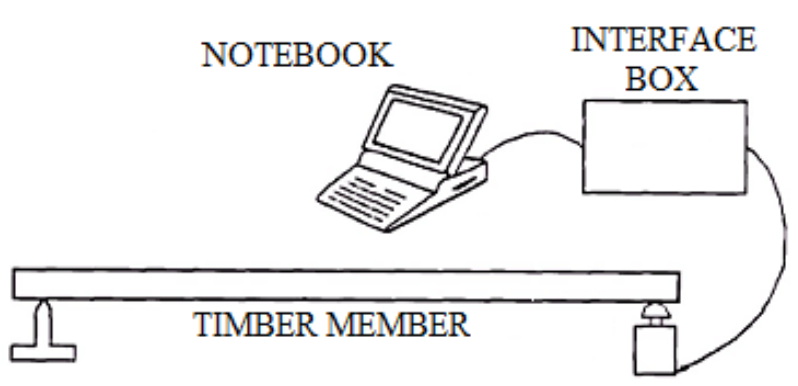

Figure 1. Schematic drawing to determine dynamic modulus of elasticity by transverse vibration test [10]

The Paricá Wood specie (Schizolobium amazonicum Herb) from the Amazon Forest [13] that can be used in various situations, including: preparation of glued laminated timber (GLULAM), OSB panels, plywood and as a raw material for cellulose pulp and paper industries [14-17].

The aim of this research is estimate of mechanical properties of Paricá Wood specie in structural members and clear specimens according to ABNT NBR 7190:1997 [7].

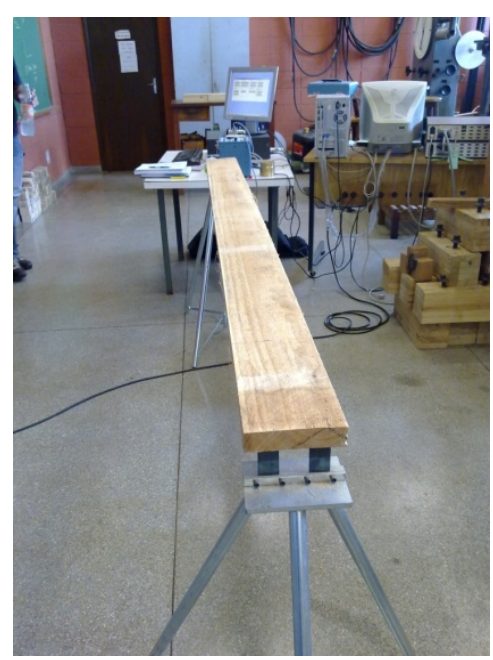

(a)

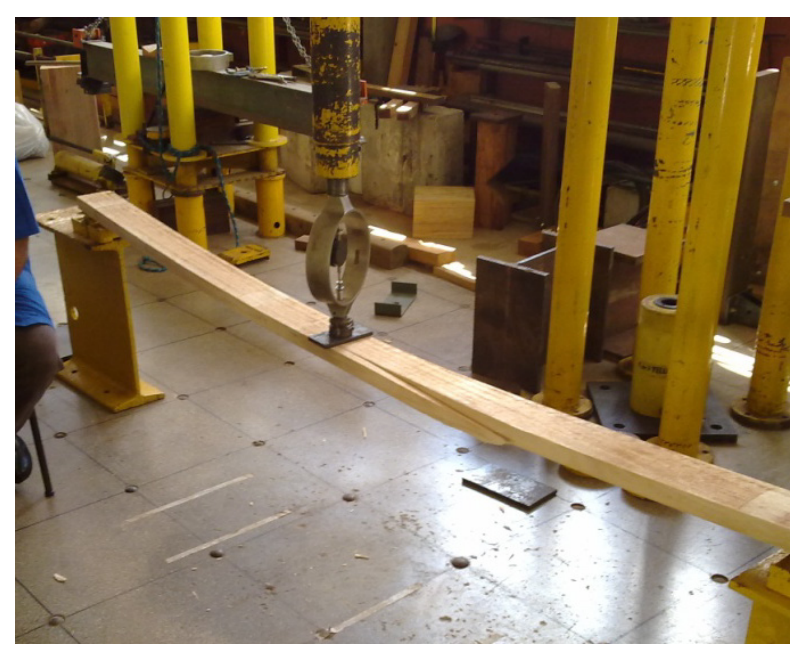

(b)

Figure 2. Structural members in tests of (a) transverse vibration (b) static bending

\section{Material and Methods}

For this research, we used 6 structure members of Paricá Wood specie from the state of Pará, with 12 years of age, with a moisture content around to $12 \%$, with the following dimensions: $3.50 \mathrm{~cm}$ of thickness, $10 \mathrm{~cm}$ of wideness and $2.50 \mathrm{~m}$ of longness in the direction to the grain.

Transverse vibration tests were performed to determine the dynamic modulus of elasticity (MOE,d) and with the same parts of the bending tests were performed at three points for determining the static modulus of elasticity (MOE,e) and modulus of rupture (MOR) (Fig. 2).

Equations 1 and 2 were using to determining of MOE,e and MOR in static bending test, respectively.

$$
\begin{gathered}
\text { MOE, } e=\frac{P \cdot L^{3}}{48 \cdot v \cdot I} \\
M O R=\frac{M_{\max }}{W_{e}}
\end{gathered}
$$

Where:

$\mathrm{P}=$ load applied in middle span $(\mathrm{N})$;

$\mathrm{L}=\operatorname{span}(\mathrm{mm})$;

$\mathrm{v}=$ maximum deflection $(\mathrm{mm})$;

$\mathrm{I}=$ inertia of structural member $\left(\mathrm{mm}^{4}\right)$;

$\mathrm{M}_{\max }=$ maximum moment applied to structural member (N.mm);

$\mathrm{W}_{\mathrm{e}}=$ inertia moment of structural member $\left(\mathrm{mm}^{3}\right)$.

After using structural members in static bending tests, clear specimens were made ( 2 of each structural member, totaling 12 specimens for each property investigated) with dimensions according to the Brazilian standard ABNT NBR 7190 [7] to estimate the following mechanical and physical properties:

- Compression parallel to the grain strength $\left(\mathrm{f}_{\mathrm{co}}\right)$;

- Elasticity modulus in compression load parallel to the grain $\left(\mathrm{E}_{\mathrm{c} 0}\right)$;

- Tension parallel to the grain strength $\left(\mathrm{f}_{\mathrm{t} 0}\right)$;

- Elasticity modulus in tension load parallel to the grain $\left(\mathrm{E}_{\mathrm{t} 0}\right)$;

- Embedment parallel to the grain strength $\left(\mathrm{f}_{\mathrm{e} 0}\right)$ (using bolt with $10 \mathrm{~mm}$ de diameter);

- Shear parallel to the grain strength $\left(\mathrm{f}_{\mathrm{v} 0}\right)$;

Using Eq. 3 according to ABNT NBR 7190 [7] were obtained the characteristic strength values.

$$
f_{k}=\left(2 \cdot \frac{f_{1}+f_{2}+f_{3}+\ldots+f_{(n / 2)-1}}{(n / 2)-1}-f_{n / 2}\right) \cdot 1.10
$$

Where:

$\mathrm{f}_{\mathrm{k}}=$ characteristic strength value $(\mathrm{MPa})$;

$\mathrm{n}=$ number of specimens used and their strength results in ascending $f_{1} \leq f_{2} \leq \ldots \leq f_{n}$, discarding the higher value if the number of specimens is odd, for not accepting $\mathrm{f}_{\mathrm{k}}$ value below $\mathrm{f}_{1}$, or $70 \%$ of the average value. 


\section{Results}

Table 1 present characteristic strength value $\left(X_{k}\right)$, average strength value $\left(\mathrm{X}_{\mathrm{m}}\right)$, standard deviation $(\mathrm{SD})$, coefficient of variation $(\mathrm{CV})$ and number of structural members $(\mathrm{n})$.

Average value detemined to MOE,e was higher than that found to MOE, $\mathrm{d}$ in $28 \%$. Although this particular difference between the elastic modulus values, Calil Junior and Mina [18] researching with 326 members of Southern Pine, found correlation coefficient between the MOE values equal to 0.98 , attesting the efficiency of method of transverse vibration.

Table 1. Strength and stiffness properties of Paricá Wood specie in member

\begin{tabular}{cccc}
\hline Properties & MOE, $\mathbf{d}_{\mathbf{~}}$ MPa) & MOE $_{\mathbf{e}}(\mathbf{M P a})$ & MOR $_{\mathbf{~ M P a})}$ \\
\hline$n$ & 6 & 6 & 6 \\
$X_{m}$ & 6868 & 8803 & 46 \\
$S D$ & 1444 & 1550 & 12.55 \\
$C V(\%)$ & 21 & 18 & 27 \\
$X_{k}$ & - & - & 39 \\
\hline
\end{tabular}

Vidaurre et al. [19] determined the modulus of rupture in bending tests on clear specimens according ABNT NBR 7190:1997 [7] for Paricá Wood specie in 4 different ages (5, 7, 9 and 11 years old) in green and dry conditions. The average value of MOR found by the authors to the dry specimens was equal to $43 \mathrm{MPa}, 7 \%$ lower than the average values determined in this study for members.

Table 2 present characteristic strength value $\left(\mathrm{X}_{\mathrm{k}}\right)$, average stiffness value $\left(\mathrm{X}_{\mathrm{m}}\right)$, standard deviation (SD), coefficient of variation $(\mathrm{CV})$ and number of clear specimens $(\mathrm{n})$.

Table 2. Strength and stiffness of Paricá Wood specie in clear specimens

\begin{tabular}{cccc}
\hline Properties & $\mathbf{f}_{\mathbf{c} 0}(\mathbf{M P a})$ & $\mathbf{f}_{\mathbf{t} \mathbf{0}}(\mathbf{M P a})$ & $\mathbf{f}_{\mathbf{v} \mathbf{0}}(\mathbf{M P a})$ \\
\hline$n$ & 12 & 12 & 12 \\
$X_{m}$ & 25 & 40 & 7 \\
$S D$ & 3.15 & 7.75 & 1.45 \\
$C V(\%)$ & 12 & 19 & 21 \\
$X_{k}$ & 20 & 27 & 5 \\
\hline Properties & $\mathbf{f}_{\mathbf{e} \mathbf{0}}(\mathbf{M P a})$ & $\mathbf{E}_{\mathbf{c} \mathbf{0}}(\mathbf{M P a})$ & $\mathbf{E}_{\mathbf{t} \mathbf{0}}(\mathbf{M P a})$ \\
\hline$n$ & 12 & 12 & 12 \\
$X_{m}$ & 18 & 8904 & 8286 \\
$S D$ & 2.45 & 1391 & 1701 \\
$C V(\%)$ & 10 & 16 & 21 \\
$X_{k}$ & 16 & - & - \\
\hline
\end{tabular}

The characteristic value of compression strength parallel to the grain $\left(\mathrm{f}_{\mathrm{c} 0, \mathrm{k}}\right)$ is equal to $20 \mathrm{MPa}$, indeed sorting Paricá Wood specie with $\mathrm{C} 20$ strength classes, as other Brazilian native species: Cedro-doce (Cedrella sp), Cedrorana (Cedrelinga catenaeformis) e a Quarubarana (Erisma uncinatum) [20], according to ABNT NBR 7190 [7].

Vidaurre et al [19] determined average values to compression strength parallel to the grain to Paricá Wood specie equal to 22,7 MPa near to determined in this research.
Scaliante et al. [21] evaluated the compression strength and elasticity modulus parallel to the grain in moisture content condition equal $12 \%$. The authors found average values of $f_{c 0}$ and $E_{c 0}$ equals to $31 \mathrm{MPa}$ and $9761 \mathrm{MPa}$, respectively. The values found by the authors they were higher to found in this research. This can be explained by the variability of the mechanical properties of wood [6, 22].

Terezo [23] realized research with Paricá Wood specie of the trees with $6,10,19$ and 28 years old. The average values of shear parallel to the grain and tension parallel to the grain were equal to $2 \mathrm{MPa}$ and $46 \mathrm{MPa}$, respectively, for four classes years of wood studied.

The ruptures modes of specimens in embedment strength parallel to grain test were cracking parallel to the grain and localized crush between hole and metal dowel [24, 25].

\section{Conclusions}

The results this research shows that Paricá wood specie presents good strength and stiffness properties and may qualify it as C20 strength classes.

\section{REFERENCES}

[1] Icimoto, F. H.; Ferro, F. S.; Varanda, L. D.; Souza, A. M.; Almeida, D. H.; Christoforo, A. L.; Lahr, F. A. R. Physical and mechanical properties of Paricá wood species treated with CCB preservative. International Journal of Materials Engineering, v. 3, p. 82-86, 2013.

[2] Logsdon, N. B.; Finger, Z.; Rosa, L. M. Caracterização da madeira de Cambará, Vochysia guianensis Aubl. Revista Engenharia Civil, n. 29, p. 57-69, 2007.

[3] Calil Junior, C.; Lahr, F. A. R.; Dias, A. A. Dimensionamento de elementos estruturais de madeira. Manole, 2003. 153 p.

[4] Calil Junior, C.; Molina, J. C. Coberturas em estruturas de madeira: exemplos de cálculo. Pini, 2010. 208 p.

[5] Lahr, F. A. R. Sobre a determinação de propriedades de elasticidade da madeira. 1983. 216 f. Tese (Doutorado) Escola de Engenharia de São Carlos, Universidade de São Paulo, São Carlos, SP, 1983.

[6] Trugilho, P. F.; Lima, J. T.; Mendes, L. M. Influência da idade nas características físico-químicas e anatômicas da madeira de Eucalyptus saligna. Revista Cerne, v. 2, n. 1, p. $1-15,1996$.

[7] ASSOCIAÇÃO BRASILEIRA DE NORMAS TÉCNICAS, ABNT, NBR 7190 - Projeto de estruturas de madeira, Rio de Janeiro, 1997, 107 p.

[8] Carreira, M. R. Critérios para classificação visual de peças estruturais de Pinus sp. 2003. 182 f. Dissertação (Mestrado) Escola de Engenharia de São Carlos, Universidade de São Paulo, São Carlos, SP, 2003.

[9] Carreira, M. R.; Dias, A. A. Critérios para classificação visual de peças estruturais de Pinus sp. Cadernos de Engenharia de 
Estruturas, v. 8, n. 34, p. 17-43, 2006.

[10] Calil Neto, C. Madeira Laminada Colada (MLC): controle de qualidade em combinações espécie-adesivo-tratamento preservativo. 2011. 120 f. Dissertação (Mestrado) - Escola de Engenharia de São Carlos, Universidade de São Paulo, São Carlos, SP, 2011.

[11] Amaya, M. L. C. Reforço de emendas dentadas com compósitos de fibras em peças de madeira. 2013. $95 \mathrm{f}$. Dissertação (Mestrado) - Escola de Engenharia de São Carlos, Universidade de São Paulo, São Carlos, SP, 2013.

[12] Segundinho, P. G. A., Cossolino, L. C.; Pereira, A. H. A.; Calil Junior, C. Aplicação do método de ensaios das frequências naturais de vibração para obtenção do módulo de elasticidade de peças estruturais de madeira. Revista Árvore, v. 36, n. 6, p. 1155-1161, 2012.

[13] EMPRESA BRASILEIRA DE PESQUISA AGROPECUÁRIA, EMBRAPA, Circular Técnica 142: Paricá (Schizolobium amazonicum), Colombo, 2007, 8 p.

[14] Cavalheiro, R. S. Madeira laminada colada de Schizolobium amazonicum Herb. (Paricá): combinação adesivo/ tratamento preservante. 2014. 103 f. Dissertação (Mestrado) - Escola de Engenharia de São Carlos, Universidade de São Paulo, São Carlos, SP, 2014.

[15] Almeida, D. H.; Scaliante, R. M.; Macedo, L. B.; Macedo, A. N.; Calil Junior, C. Madeira laminada colada (MLC) da espécie Paricá. Madeira: Arquitetura e Engenharia, v. 12, p. 71-82, 2011.

[16] Ferro, F. S.; Icimoto, F. H.; Souza, A. M.; Almeida, D. H.; Christoforo, A. L.; Rocco Lahr, F. A. Produção de painéis de partículas orientadas (OSB) com Schizolobium amazonicum e resina poliuretana à base de óleo de mamona. Scientia Forestalis (IPEF), v. 43, p. 313-320, 2015.

[17] Stella, J. C. A influência de variáveis do ciclo de prensagem e gramatura de colas nas propriedades mecânicas de compensados de Paricá (Schizolobium amazonicum). 2009. 50 f. Monografia (Graduação) - Universidade Federal do
Paraná, Curitiba, PR, 2009.

[18] Calil Junior, C; Miná, A. J. S. Vibração transversal: um método eficiente para classificação de peças estruturais de madeira. Revista Brasileira de Engenharia Agrícola e Ambiental, v. 7, n. 2, p. 335-338, 2003.

[19] Vidaurre, G. B.; Pizzol, V. D.; Arantes, M. D. C.; Lombardi, L. R. Influência da idade na resistência à flexão e compressão paralela da madeira de Paricá. In: Encontro Brasileiro em Madeiras e em Estruturas de Madeira, EBRAMEM, 13, Vitória - ES, Brasil, 2012.

[20] Dias, F. M.; Lahr, F. A. R. Estimativa de propriedades de resistência e rigidez da madeira através da densidade aparente. Scientia Forestalis, n. 65, p. 102-113, 2004.

[21] Scaliante, R. M.; Almeida, D. H.; Macedo, L. B.; Macedo, A. N.; Calil Junior, C. Ensaio de fluência e de compressão paralela às fibras para situações da madeira à umidade de equilíbrio e saturada. Madeira: Arquitetura e Engenharia, v. 12, p. 19-30, 2011.

[22] Ferro, F. S.; Icimoto, F. H.; Almeida, D. H.; Christoforo, A. L.; Lahr, F. A. R. Verifications of tests conditions to determine the compression modulus of elasticity of wood. International Journal of Agriculture and Forestry, v. 3, p. 66-70, 2013.

[23] Terezo, R. F. Avaliação tecnológica do Paricá e seu uso em estruturas de madeira laminada colada. 2010. 200 f. Tese (Doutorado) - Universidade Federal de Santa Catarina, Florianópolis, SC, 2010.

[24] Almeida, D. H. Análise das resistências de embutimento e de compressão para madeiras de Pinus e Eucalipto. 2011. $100 \mathrm{f}$. Monografia (Graduação) - Universidade Estadual Paulista, Itapeva, SP, 2011.

[25] Almeida, D. H. Proposta de método de ensaio para a determinação da resistência da madeira ao embutimento. 2014. 131 f. Dissertação (Mestrado) - Escola de Engenharia de São Carlos, Universidade de São Paulo, São Carlos, SP, 2014. 